Институт за српску културу - Приштина, Аепосавић

\author{
ПРОАОР ЈЕАИНИЦА 13. КОРПУСА НОВЈ \\ НА КОСОВО 1944. ГОАИНЕ И УГРОЖАВАЮЕ \\ ОАСТУПНИЦЕ ГРУПИ АРМИЈА „Е“**
}

$A \bar{u} c \bar{u} p a \kappa \bar{u}:$ РаА, на основу грађе похрањене у Војном архиву, као и адекватне митературе, обрађује борбена Аејства 13. корпуса Народноослободилачке војске Југославије на пресецању оАступнице групи армија „Е“ на правцу оА Скопьа према Косовској Митровици, у периоду оА 15. октобра до 20. новембра 1944. године. Посебна пажња посвећена је сарадњи са новим савезницима - Бугарима, који су са својом 2. армијом, након борби коА Ниша, наступали према Косову.

РаА се не бави читавом Косовском операцијом, тачније, не обрађује акције партизана из правца Метохије (које ће свакако бити поменуте), већ искьучиво продор снага из правца Србије и угрожавање виталне Аолине Ибра.

Кьучне речи: Србија у Аругом светском рату, Косово и Метохија, група армија „Е“, 13. корпус Народноослободилачке војске Југославије, Косовска операција.

Продором групе Аивизија Народноослободилачке војске Југославије у Србију у јесен 1944. године почема је завршна фаза борби за ослобођење земье. Поседањем Србије, Народноослободимачки покрет је решио битку за Југославију тако што је Аобио солидну стратегијску и економску основицу за Ааље борбе, али и прилив новог ьудства (Petranović 1992: 633). У то време у Србији су дејствовале, осим јеАиница пребачених из Босне и Црне Горе, пет Аивизија на простору у сливу Тимока и јужно оА Ниша, сврстаних у Ава корпуса. Након спајања са трупама 3. украјинског фронта Црвене армије и пресецања комуникације у Аолини Мораве, створила се могућност отпочињања битке за БеограА. Ослобођење БеограАа и напредовање на север и запаА подразумевали су сређивање стања у позадини, тачније контролисање свих значајних комуникација кроз Србију, како се не би угрозио фронт главних снага, али и спречило повлачење Немаца из Грчке, које је било у току.

\footnotetext{
* научни сарадник, d.velojic@yahoo.com

** Рад је написан у оквиру пројекта Матееријална и gуховна кулӣура Косова и Метиохије (ев. број 178028), који је одобрило и финансира Министарство просвете, науке и технолошког развоја Републике Србије.
} 
Немачка група армија „Е“ из Грчке се повлачияа Аолинама Мораве и Вардара на север како би се спојила са осталим снагама и оформила фронт у Мађарској. Брз налет Црвене армије, након Јашко-кишињевске операције, међутим, претио је Аа ове планове омете и немачке снаге разАвоји. Заузимањем Бугарске и Румуније совјетске снаге избиле су на југословенску границу и спојиле се са јеАиницама НОВЈ (Beogradska operacija 1989: 148-158). На састанку у Москви Јосип Броз Тито је са Стаљином утаначио услове југословенско-совјетског садејства и даљег напредовања након проласка кроз Србију (Petranović 1988: 332-336). ПореА тога, у Крајови су са преАставницима бугарског отечественог фронта усклађене акције на југу и истоку Србије, с обзиром на њихове молбе за учешће бугарских снага у борбама против Немаца (Petranović 1988: 339-341). Бугарске снаге учествовале су у операцији за ослобођење Ниша, где нису показале нарочити квалитет (опширније: Трифуновић-Никомић и Ар. 1950). ${ }^{1}$ Упркос томе, салејство југословенско-бугарских снага наставило се и у операцијама на Косову.

Територија Косова и Метохије добила је на војничком значају након ослобођења Ниша и пресецања одступнице Немцима на север. У том скучају, правац повлачења групе армија „Е“ водио би из Скопьа према Косову и Аање преко Новог Пазара или Краљева у Босну. У ту сврху, командно место група армија „Е“ премештено је из Солуна у Косовску Митровицу. ${ }^{2}$ Аетаљни план је преАвидео неколико праваца повмачења преко Косова:

„После оперативног пробоја противника са обе стране Аунава у рејон Београда и са овим насталог прекиАа свих досадањих позадинских (саобраћајних) веза, настала је за Групу армија $\gg$ Е нужност Аа промени правац ка сев. зап. према територији између Јадрана и Саве и Аа тако отвори нове veze і добије наслон на сопствене снаге на северу Балкана (Команда 2. окм. армије). Циь ове наше операције је оА сада Аа се целокупне снаге Југоистока прикупе на територији западне Хрватске, Аа би се оАавде могма повести одбрана југ. ист. границе Рајха и то по могућству офанзивно. За ово, Група армија $\gg Е$ мора за себе Аа ослобоАи борбом и Аржи отвореним следеће правце путева који воде на просторију Мостар-Сарајево:

Пут А: Урошевац-Призрен-Кукес-СкаАар-Подгорица-Никшић-Требиње-Мостар.

Пут Б: Рашка, односно Митровица - Нови Пазар - Сјеница - Пријепоље Вишеград, односно Пријепоље-Пьевьа-Горажде-Рогатица-Сарајево:

Пут Ц: Краљево-Чачак-Ужице а оАавАе, као Ц1, Аање води преко ВишеграАаРогатице за Сарајево. Као Ц2 Аање води преко Зворник-Тузма за Аобој.

1 Видети такође: „Niška operacija“, Vojna enciklopedija, VI, Urednik: Nikola Gažević, Beograd: Vojnoizdavački zavod, 1970, 109-110.

2 Zbornik dokumenata i podataka o narodnooslobodilačkom ratu (у Аањем тексту: Zbornik), Tom XII, knj. 4, Beograd, Vojnoistorijski institut, 1976, Аневник групе армија „Е“ за 14. 10. 1944. 
Предуслов за планско одвијање током отварања нових веза је солидно обезбеђење ист. бока Групе армија према руско-бугарским и бандитским снагама које теже напреА према зап.“"

Приметно је из наведеног пиана да је рејон Косовске Митровице и Рашке кьучан као раскрсница путева који воде за Краљево и Нови Пазар, којима би се већина немачких снага извлачима према Босни. Комуникација означена као пут А бима је алтернатива, што се види и из наређења команданта Југоистока фелдмаршала Вајкса: „Рачунати са тим да ће можАа делови групе армија „Е“ морати себи да крче пут преко СкаАра-Никшића-Требиња ка Мостару.“4

Ова комуникација бика је у деку Црне Горе константно угрожавана оА стране 2. корпуса НОВЈ.

$A$ а би се обезбедило уредно повлачење, команда групе армија „Е“ на брзу руку образовала је фронт између Урошевца и Крањева и обезбедила комуникацију оА Новог Пазара према Вишеграду (Oslobodilački rat 1957: 372).У ту сврху формиране су борбене групе „Аангер“ и „БреАов“ ради заштите источних праваца, као и група „Скендербег“ у Метохији. ${ }^{5}$ Ове јединице имале су задатак Аа обезбеде извлачење 22. армијског корпуса и делова осталих јединица из Грчке. На територији северне Албаније и Црне Горе Аејствовао је 22. корпус, Аок је у рејону Краљева формиран корпус „Мимер“ (оА остатака 34. корпуса. Група „Аангер“ распоређена је била у рејону Куршумлије и затварала је правац из Прокупьа према Подујеву и Приштини, Аок је група „Бредов“ затварала правац из Бујановца према Гњилану и Приштини (Oslobodilački rat 1957: 374-375). ПореА тога, на територији Косова, између ових борбених група, налазило се око 6.000 балиста поА немачком командом (Colić 1988: 266). Према извештају команде групе армија „Е“, на оАсеку Косовска Митровица - Рашка - Нови Пазар налазило се око 2.400-3.000 четника, који су Немцима у почетку штитили бокове, а затим кренули заједно у повлачење. Занимьив је утисак Немаца који је утицао на њихову преАострожност према четницима: „Аокме гоА постоје зајеАнички интереси-уопште мир. Ако виде могућност успеха, безусловно треба очекивати препаде на немачки Вермахт, нарочито на одвојене групе.“6

3 Ист̄о, Аневник групе армија „Е“ за 18. 10. 1944.

4 Истио, Аиректива команданта Југоистока оА 14. 10. 1944. командантима групе „Србија“ и 2. окмопне армије за регулисање командних односа.

5 Пуковска борбена група „Скендербег“ настама је расформирањем истоимене Аивизије која је десеткована у Андријевичкој операцији. Са своја три мовачка и јеАним јуришним батаљоном, укупне јачине око 7.000 војника (оА тога 4.000 морнара пристиглих из Грчке) размештена је на простору Пећ-Ђаковица-Призрен. Исӣо, Наређење команде групе армија „Е“ о преформирању дивизије „Скендербег“.

6 Исйо, XII, 4, 714. Извештај команде групе армија „Е“ оА 11. новембра 1944. команданту Југоистока о постигнутом споратзуму са четницима који се повмаче према Фочиза зајеАничка дејства против јединица НОВЈ. 
На Косову и Метохији у то време није бимо јачих снага НОВЈ. Постојао је Оперативни штаб за Косово и Метохију, потчињен Главном штабу Србије, са којим је и ускцађивао дејства. У јесен 1944. године поА командом овог штаба налазияо се пет бригада, као и Аве пристигле из Албаније. ${ }^{7}$ Како ове јеАинице нису биме Аововне Аа се супротставе немачкој групи армија „Е“, са територије јужне Србије, због своје близине, ангажован је 13. корпус НОВЈ, као и бугарска 2. армија.

Питање учешћа бугарских снага у операцијама у Југоскавији поставимо се након продора Црвене армије и расформирања бугарске царске војске. Новоформирана влада отечественог фронта, предлагала је, у циљу искупьења, помоћ југословенским снагама, што је и замовено на састанку са Титом у Крајови. ${ }^{8}$ Иако стварне потребе за бугарском помоћи није бимо, с обзиром на снагу НОВЈ, а узевши у обзир чињеницу Аа је већина војничког и старешинског састава прешиа из царске војске (Mitrovski-Glišić i dr. 1977: 197-203), ипак се изашло у сусрет овој молби. ${ }^{9}$ На правцу према Косову учествовала је 2. бугарска армија, потчињена команди 3. украјинског фронта Црвене армије. Ангажовање бугарских снага још за време Нишке операције изазвало је незадовољство у ГАавном штабу Србије, пошто су оптуживане за пљачку и некоректан однос према становништву. Упркос томе, садејствоваме су јеАиницама НОВЈ у Косовској операцији.

ГАавни правци наступања југословенско-бугарских снага били су према Приштини, преко Подујева и Гњилана, што је и најупорније брањено оА Немаца. Правцем из рејона Куршумлије према Подујеву наступали су Аемови 2. бугарске армије, са задатком да овладају Малим Косовом и продуже Аејство према Приштини. Као помоћна група на овом правцу дејствовала је 24. Аивизија НОВЈ са задатком заузимања Вучитрна и Косовске Митровице и пресецања комуникације Приштина-Рашка. Ова дивизија је за конкретан задатак била одговорна директно ГАавном штабу Србије, пошто су јој намењене и мобимизацијска умога на територији Косова, али и координација осталих цокалних јеАиница:

„...]са вашим јединицама извршите покрет општим правцем: ПрокупьеКуршумлија-Приштина са задатком:

7 Мисли се на 3. и 5. бригаду НОВ Албаније које су, према споразумом са Врховним штабом НОВЈ, упућене у Метохију почетком октобра (Colić 1988: 263).

8 Аемегација бугарског отечественог фронта изнела је молбу за учешћем бугарских снага у борбама против Немаца, као искупьење за недема које су Бугари починили у току рата (Mitrovski-Glišić i dr 1971: 189-231).

9 Самм Тито је касније изјављивао да је апсокутно непотребно бимо учешће Бугара у овим операцијама, али се изашло у сусрет како би им се пружила прилика за рахабилитацију (видети изјаве у мисту Нароgна армија из 1977. и говор на промоцији приликом именовања за почасног доктора војних наука 1976. године). 
а) Садејства бугарским снагама које оперишу ка Косову. Овим бугарским снагама садејствоваће и јединице Космета са којима одмах по доласку на ту територију ступите у везу ради међусобне сарадње.

б) Потпомагања јединица Космета у вршењу мобилизације, политичком раду међу народом и постављању читаве власти на територији Космета.

По питању пиена Ао Аањег наређења поступите овако: сви непријатељски магацини оружја који се налазе у појединим гарнизонима и уопште на територији Космета припадају нама. остали плен заплењен у борбама било оА стране бугарских, бимо од стране наших јединица дели се на пола.

Напомињемо Аа сва искрсла питања са бугарским јединицама решавате споразумно са њиховим штабовима избегавајући при томе жучне расправе и ма какве сукобе. Ми смо предузели потребне мере Аа сва питања плена на нашој територији решимо у нашу корист [...] У извршењу заАатка бићете поА нашом непосреАном командом. ${ }^{\text {"10 }}$

Јужно оА ове групе, из рејона Аебана и МеАвеђе наступала је 12. бугарска Аивизија са 5. косовско-метохијском бригадом, такође као поАршка главним снагама на правцу према Приштини. На југу су Аругим главним правцем, из Бујановца према Гњилану и Приштини, наступале 46. Аивизија НОВЈ са 2. бугарском коњичком Аивизијом, подржане 2. и 3. косовско-метохијском бригаАом, које су аејствовале према Урошевцу (Colić 1988: 264).

Иако је напаА био преАвиђен за 23. октобар, већ 15. су Аелови бугарске 2. армије напали Куршумлију и натерали борбену групу „Аангер“ на повлачење према Куршумлијској бањи. Пристизањем 24. Аивизије НОВЈ ${ }^{11}$ Немци су се повукли на минију Преполац-Мердаре и ту стабилизовали одбрану. Упркос овоме, мишьење је Аа је напаА ипак био слабо изведен:

„Аа су бугарска 2. армија и 24. Аивизија биме мало енергичније, могме су Аа продру на Мало Косово и на тај начин изврше свој задатак, јер су за то постојали сви остали услови. Али недовољно ангажовање ових јеАиница, посебно тенковске бригале, омогућияо је Немцима Аа утврде своје положаје и Аа их задрже све Ао 31. октобра“" (Oslobodilački rat 1957: 375).

У ту сврху штаб 24. Аивизије издао је наређење Ибарском одреАу, који се налазио на Копаонику, за садејство главним снагама. ${ }^{12}$ Уз одговор, штаб Ибарског одреАа Аоставио је податке који су указивали на неометано повмачење Немаца, усмеА слабог ангажовања бугарских трупа. Наведено је Аа

10 Војни архив (ВА), фонА НОВЈ, к. 181, ф. 3, А. 38, 1. наређење Гцавног штаба Србије 24. Аивизији оп. бр. 92 оА 18. октобра 1944.

11 Авадесет четврта Аивизија упућена је ради садејства Бугарима и напредовања на помоћном правцу. У извештају ГАавног штаба Србије бугарској 2. армији наводи са Аа је пореА мокалних косовско-метохијских бригаАа упућена јеАна Аивизија ради садејства општим правцем Прокупье-Подујево-Приштина. Истио, А. 40, 1.

12 Зборник, I, 19, 682. Наређење штаба Ибарског одреда оА 23. октобра штабовима батаљона за садејство са 24. Аивизијом. 
из правца Косовске Митровице ка Рашки и Новом Пазару Немци дневно евакуишу по 2-3.000 војника, 200 возила и 10-20 тенкова и топова. Немачких посада било је у Митровици и Рашки, ојачаних артиьеријом, а Ауж комуникације према Новом Пазару, примећено је јако обезбеђење на тачкама:

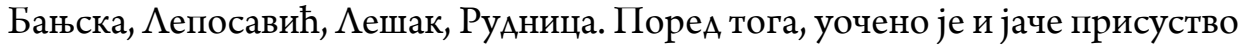
балиста на падинама Копаоника. ${ }^{13}$

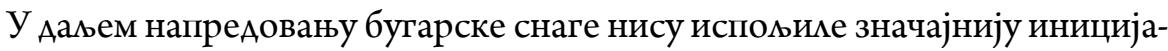
тиву и њихова дејства свела су се на насилно извиђање и борбе мокалног карактера. Међутим, 24. Аивизија прешла је у енергичније гоњење и угрозила саму Косовску Митровицу. Неактивност Бугара искористили су Немци и Аовели из Митровице свежа појачања, која су извршила контранапаА и оАбацила 24. Аивизију. НапаА на немачке положаје код Преполца обновьен је тек 1. новембра, уз јаче ангажовање Бугара, тако да је немачка одбрана повучена на резервне положаје, где се одржала до повлачења групе армија „Е“Аолином Ибра. УслеА великих губитака, 24. Аивизија замењена је 22. Аивизијом, која је наставила Аање операције (Oslobodilački rat 1957: 376). ${ }^{14}$

На јужном правцу дејства су отпочема знатно касније. Како напаА из правца Куршумлије није Аао очекиване почетне резултате, инсистирано је Аа 13. корпус енергичније напаАа према Приштини. ${ }^{15}$ ЈеАинице 46. Аивизије НОВЈ и 2. бугарске коњичке Аивизије планираяе су напаА ради пресецања везе између Бујановца и Гњилана, као и ради уништења балиста на простору Трновца. ${ }^{16}$ НапаА који је уследио није Аао жељене резултате, упркос разбијању балиста, којих је, како се процењује, на том сектору бимо око 2.500. ЈеАинице 46. Аивизије успеле се Аа заузму прве пограничне положаје, Аок су Бугари, усмеА великих губитака, зауставьени. ${ }^{17}$

Општи напад отпочео је 8. новембра, истовремено са немачким повлачењем. Наступајући иза Немаца, групе из састава 46. Аивизије и 2. бугарске коњичке Аивизије истог Аана ушие су у Бујановац, обезбеђујући околна сема Трновац и Кончув. Косовско-метохијске бригаде пресекме су комуникацију оА Бујановца према Куманову, прешле Скопску Црну Гору и ушие на Косово. ${ }^{18}$

13 ВА, НОВЈ, к. 1081, ф. 6, А. 5. извештај Ибарског одреАа штабу 24. Аивизије оА 28. октобра 1944.

14 У извештају 13. корпуса наводи се Аа је 24. Аивизија смењена и враћена у Ниш Аа би се средила и испитали узроци великих и непотребних губитака које је имала у борбама на Косову. 3борник, I, 14, 594. Извештај 13. корпуса ГАавном штабу Србије оА 10. новембра 1944.

15 ГАабни штаб Србије издао је 27. октобра наређење за енергично наступање на сектору Бујановца, као и упућивање додатних јединица према Косову. ВА, НОВЈ, к. 181, ф. 3, А. 1. Наређење Гкавног штаба Србије штабу 13. корпуса оп. бр. 107 оА 27. октобра 1944.

16 Зборник, I, 14, 330. Заповест штаба 46. Аивизије оА 27. октобра 1944.

17 ВА, НОВЈ, к. 1340, ф. 6. А. 3. Извештај штаба 46. Аивизије штабу 13. корпуса оА 1. новембра 1944.

18 Зборник, I, 14, 594. Извештај 13. корпуса ГАавном штабу Србије оА 10. новембра 1944. 
О самом ослобођењу Бујановца постоје размичити извештаји, пошто су оА стране Команде месковачког подручја у штаб 13. корпуса стигле информације Аа је бугарска артиьерија Ао 12. новембра тукма граА и немачке јеАинице у њему. ПореА тога, упућена је замерка корпусних обавештајаца истој команди да је нетачна информација о базирању око 20 немачких бомбардера и око 60 моваца на Косову, као и о Аотирању материјала вазАушним путем:

\footnotetext{
„Напомињемо Аа је тачан извештај оА огромне користи и Аа обратно нетачан извештај преАставьа велику опасност која може за собом имати тешких последица па и повући најтежу одговорност те ми који радимо на обавештајној служби морамо са тим бити увек начисто. МожАа ни јеАна служба не захтева толико опрезности и сталног старања као наша. У извештајима се треба приАржавати датих упутстава. За нас је оА највећег значаја знати са колико се сигурности можемо осмонити на јеАан извештај јер смо одговорни за Аавање нетачних података. “19
}

Ово показује колико су новоосновани месни органи олако схватали своју Аужност, нарочито у обавештајно-безбедносном погмеАу. Штаб 13. корпуса, иако формиран неки месец раније, састојао се већим Аелом оА искусних и обучених каАрова, нарочито обавештајаца. Овакви пропусти месних органа нису могли бити толерисани, нарочито након инцидента са растурањем непријатеьских метака у ослобођеном Аесковцу, о чему дотична ( кесковачка) команда није имала информацију. ${ }^{20}$

Након ослобођења Бујановца ослобођено је и Гњилане 16. новембра. Приликом ослобађања овог града Аошло је Ао инцидента међу савезницима, што је и убрзало повратак бугарских снага. У извештају Гцавног штаба за Србију Врховном штабу НОВ и ПОЈ наводи се Аа је штаб бугарске Аивизије која је ослобађала Гњилане преговарао са балистима Аа их без борбе пусте у граА. Овај споразум осујетили су обавештајци 46. Аивизије и 13. корпуса и, након енергичних протеста, преговори су прекинути. У Гњияане су ушле југословенске и бугарске јединице истовремено. ${ }^{21}$ Сличан случај поновио се и коА бугарске 6. Аивизије која је оперисала према Приштини. Бугари су хтели Аа избегну борбу са балистима на тај начин што југосмовенске јединице не би заједно са њима ишме на Косово. ${ }^{22}$

У извештају 46. Аивизије, као оправдање за споро напредовање, наводи се бугарска неактивност, а затим и недостаци у самом јединицама НОВЈ. Пре свега, организација самих јединица није бима потпуна. Везе и обавештајна скужба слабо су функционисале. Проблема је бимо и са исхраном и одевањем (велики

19 ВА, НОВЈ, к. 591, ф. 3, А. 11. Штаб 13. корпуса Команди месковачког подручја пов. об. бр. 123 оА 13. новембра 1944.

20 Истйo.

21 Ист̄о, к. 181, ф. 6, А. 3. Извештај ГАавног штаба Србије Врховном штабу НОВ и ПОЈ оп. бр. 142 оА 18. новембра 1944.

22 Истйo. 
проценат ьудства био је потпуно бос, Аок је $80 \%$ бимо без икаквог покривача), због чега се део војника разболео. ${ }^{23}$ Ово је свакако симптоматично за све новоформиране јединице на територији Србије у мето и јесен 1944. године, јер је нагли пријем ьудства и њихово преурањено ангажовање у борбеним дејствима са собом повцачимо неадекватно организовано интендантско обезбеђење, што је за последицу имало недовољан учинак оперативних дивизија.

Зачеље групе армија „Е“ почемо је Аа напушта Косово већ 16. новембра. Истовремено, група „Скендербег“ је из Метохије кренума за Митровицу, пошто је пропао покушај пробоја преко Чакора за Црну Гору. То је, са јеАне стране, олакшало јединицама НОВЈ и 2. бугарске армије наступање и ослобађање Косова. Приштина је ослобођена 19, а Митровица 22. новембра. Са Аруге стране, главни заАатак, пресецање оАступнице овим немачким снагама и њихово уништење, није извршен. ЈеАинице групе армија „Е“ успешно су се извукле Аолином Ибра према Санџаку или Краљеву, Аок су балисти претрпели осетне губитке. ЈеАино што се могмо преАузети бимо је угрожавање ибарске долине, што је и учинио Ибарски одреА, Аејствујући са Копаоника. ${ }^{24}$ Међутим, ова дејства нису озбиьније угрозима повмачење, пошто су Немци комуникацију одлично обезбедили. Као размози за неуспех, тачније за изостанак крупнијих резултата, наводе се, пре свега, неактивност и неоАкучност Бугара, а затим и пропусти у самој организацији новоформираних јеАиница НОВЈ, о чему је већ речено. Као проблем је навеАено и оАсуство јеАног зајеАничког оперативног тела, које би руководимо операцијом. Бугарске снаге су након тога повучене у рејон Ниша и $е$ есковца, а затим у Бугарску, Аок су јединице НОВЈ наставиле гоњење. У сваком случају, у овим четрАесетодневним борбама ослобођени су Косово и Метохија и створени су услови за омасовљавање Народноослободилачког покрета.

\section{НЕОБЈАВЉЕНИ ИЗВОРИ}

Војни архив, фонА Народноослободилачке војске Југославије.

\section{ОБЈАВАЕНИ ИЗВОРИ}

Zbornik dokumenata i podataka o narodnooslobodilačkom ratu.

23 Zbornik, I, 15, Извештај 46. Аивизије штабу 13. корпуса оА 12. новембра 1944.

24 „Слажемо се са садањим распоредом ваших снага на Копаонику, али сматрамо Аа и пореА надмоћнијих непријатељских снага на ибарској комуникацији имате прилике за Аејства на непријатеља. Арским препадима мањих одењења (чета) непосредно на непријатељске посаде на комуникацији треба изненађивати непријатеља и наносити му губитке. На овај начин успоравати непријатеьски саобраћај дуж комуникације.“ BА, НОВJ, к. 181, ф. 3, А. 54. Наређење Гмавног штаба Србије штабу Ибарског оАреАа оп. бр. 126 оА 13. новембра 1944. 


\section{АИТЕРАТУРА}

Beogradska operacija 1989: Beogradska operacija 20. oktobra 1944. Beograd: Institut za vojnu istoriju Ministarstva odbrane SSSR: Vojnoistorijski institut JNA.

Vojna enciklopedija 1970: Vojna enciklopedija. Ur. Nikola Gažević. Beograd: Vojnoizdavački zavod.

Mitrovski-Glišić i dr. 1971: Boro Mitrovski, Venceslav Glišić i Tomo Ristovski. Bugarska vojska u Jugoslaviji 1941-1945. Beograd: Međunarodna politika.

Oslobodilački rat 1957: Oslobodilački rat naroda Jugoslavije 1941-1945, II, Beograd: Vojnoistorijski institut.

Petranović 1988: Branko Petranović. Istorija Jugoslavije 1918-1988, II, Beograd: Nolit.

Petranović 1992: Branko Petranović. Srbija u Drugom svetskom ratu 1939-1945. Beograd: Vojnoizdavački i novinski centar.

Trifunović-Nikolić i dr. 1950: Dimitrije Trifunović, Dobrosav Nikolić i Vojin Popović. „Borbe za oslobođenje Niša 1944. godine“, Vojno-istorijski glasnik, 3/1950, 9-36.

Colić 1988: Mladenko Colić. Pregled operacija na jugoslovenskom ratištu 1941-1945. Beograd: Vojnoistorijski institut. 
Dalibor Z. VELOJIĆ

\title{
THE BREAKTHROUGH OF THE 13TH CORPUS UNITS OF NLAY ON KOSOVO IN 1944 AND THREATENING OF THE RETREAT OF GROUPS OF ARMIES 'E'
}

\begin{abstract}
SUMMARY
Kosovo operation led from October 15th to November 20th of 1944, had for its objective the interception of the retreat of Deutsch group of armies ' $E$ ' in Kosovo and in the valley of the river of Ibar and its destruction. Out of the available forces engaged in these fights was the 13th Corpus of National-Liberation Army of Yugoslavia, more precisely its 46th and 24th, and later on 22nd division, including local Kosovo-Metohian brigades. Out of the Bulgarian army as the ally from the Fatherland front the second army was engaged. Action directions were going from Kuršumlija, toward Podujevo and Prishtina and from the area of Bujanovac, via Gnjilane toward Prishtina. Due to the non-unique command, inactivity of Bulgarian forces, strong Deutsch side security, fights lasted around forty days. Kosovo was set free, but the main objective, interception of Deutsch retreat failed, so group of armies 'E' managed to retreat by the Ibar's valley. After these fights, Bulgarian force retreated, and NLAY pursued its search.
\end{abstract}

Key words: Serbia in the WWII, Kosovo and Metohija, Groups of Armies 'E', 13th Corpus of National-Liberation Army of Yugoslavia, Kosovo operation.

РаА је преАат 4. октобра августа 2018. године, а након мишьења рецензената, оАлуком одговорног уреАника Башииине, одобрен за штампу. 